\title{
Managed Migration of Coast Redwoods: Subjectivity of Stakeholders in Oregon's Land Use Planning Community
}

\author{
Jeffrey Jenkins ${ }^{1} \&$ Michael W. Jenkins ${ }^{2}$ \\ ${ }^{1}$ Gallo Management Program, University of California, Merced, United States \\ ${ }^{2}$ Department of Environmental Studies, University of California, Santa Cruz, United States \\ Correspondence: Jeffrey Jenkins, Gallo Management Program, University of California, 5200 Lake Road, Merced, \\ CA., 95343, United States. Tel: 1-831-854-7296. E-mail: jeff.jenkins@ucmerced.edu
}

Received: May 19, 2017

doi:10.5539/enrr.v7n3p1
Accepted: May 31, 2017

Online Published: June 12, 2017

URL: https://doi.org/10.5539/enrr.v7n3p1

\begin{abstract}
The Earth's climate is changing at a faster pace than the slow natural adjustment rates of most species to their rapidly shifting habitat conditions, especially for long-lived tree species, such as the iconic coast redwood Sequoia sempersqvirens. This may leave some species stranded in less than optimal environments, resulting in population extinctions and/or the need for human-assisted migration. However, the implementation of assisted migration does not come without economic, legal, political, ecological, and ethical issues. One of the most important and complex social questions regarding assisted migration is that of the land use planning community in the area being considered. This article explores the subjective beliefs among these stakeholders regarding managed migration of coast redwood trees into suitable habitats in Oregon. Q-methodology was used to structure the complexity of participants' subjective beliefs into a few manageable themes to reveal broader socio-economic and environmental perspectives and shared ways of perceiving and valuing the relationship between social, economic, and environmental concerns. The findings of this study suggest two main factors 1) positively ranked values that align on new perspectives of utilitarian ecological values, and 2) positively ranked values that align on a land based communitarian perspective. This convergence suggests an ecologically aware land management ethos as opposed to the view of favoring human's dominion over nature, and therefore bolsters the potential for the future success of managed migration of coast redwoods into suitable habitats in Oregon given the state's existing land use policy.
\end{abstract}

Keywords: climate change, assisted migration, managed migration, coast redwood, conservation, Q method

\section{Introduction}

\subsection{Global Climate Change Impacts to Species Distribution}

Ecosystems are rapidly being transformed into configurations that differ in composition and/or function from present and past systems. This transformation, is recognized as a consequence of environmental alteration and changing species distributions owing to climate and land use change (Harris, Hobbs, Higgs, \& Aronson, 2006; Root \& Schneider, 2006). Climate change scenarios and species distribution models predict modest to major geographic shifts in the distribution of species over the next century. However, the magnitude of the changes varies depending on which emissions scenarios and circulation models are used, species altitudinal and latitudinal distribution, and on the ability of species to migrate (Douhovnikoff \& Dodd, 2011). The response of species to past (Benton \& Twitchett, 2003) and recent (Root et al., 2003) climate change and the fact that the Earth is set to become warmer than any period in the last 40 million years (Houghton et al., 2001) raises the concern that anthropogenic climate change could act as a major cause of extinctions soon (Thomas, Cameron, Green, \& Williams, 2004). Over the last 30 years climate change has resulted in numerous shifts in the abundances and distribution of species (Parmesan \& Yohe, 2003). The Earth's climate is changing at a faster pace than the slow natural adjustment rates of most species to shifting habitat conditions (Davis \& Shaw, 2001; Hulme, 2005), especially for long-lived tree species.

\subsection{Floristic Response to Climate Change in the Western United States}

Broad-scale changes in forest composition and structure are occurring in many parts of North America owing to changes in: temperature (Adams et al., 2009; Allen et al., 2010), hydrological regime (Boyer, 1982; Nemani et 
al., 2003), prevalence and magnitude of wildfire (Westerling et al., 2011), and occurrence of insect pests and pathogens (Crowl, Crist, Parmenter, Belovsky, \& Lugo, 2008; Metz, Varner, Frangioso, Meentemeyer, \& Rizzo, 2013). A recent study of the endemic flora of the California Floristic Province by Loarie et al. (2008) suggests that under extreme and moderate scenarios of climate change that the suitable habitat for many species native to California will shift from inland to coastal areas, and that coastal species are predicted to undergo northward range shifts. Models projecting vegetation cover change over the next 100 years suggest that in western North America needle-leaf evergreen trees will be reduced by approximately 15\% (Jiang et al., 2013). Where the bioclimatic envelope changes but there is no immediate biotic response and the abiotic infrastructure remains intact, systems can initially remain as relicts of the historic system (Hobbs, Higgs, \& Harris, 2009). Such is the case with coastal redwoods of northern California, which are dying off in the southern extent of their range along the Big Sur coast given changes in precipitation and temperature. However, future climatic predictions show that potentially suitable habitat for coast redwoods will soon exist along the southern Oregon coast, an increase in range latitudinally equivalent to that of the loss of suitable habitat throughout the species' current southern extent. This study investigates the subjective beliefs of environmental change and lands management among the Oregon land use planning community, particiularly regarding assisted migration of coast redwoods to the Oregon coast.

\section{Material Studied}

\subsection{The Coast Redwood}

In the conifer forest of northern coastal California, the distribution of the iconic coast redwood (Sequoia sempervirens) is restricted to a narrow $(\sim 50 \mathrm{~km})$ belt $900 \mathrm{~km}$ long from $\sim 42^{\circ} \mathrm{N}$ to $36^{\circ} \mathrm{N}$ (Johnstone \& Dawson, 2010). Coast redwood is the tallest living tree species, attaining heights of $115 \mathrm{~m}$ (Sawyer et al., 2000a) and notably long-lived, with some individuals exceeding 2000 years in age (Noss, 1999). The redwood ecoregion has been identified by the World Wildlife Fund as being in the highest conservation priority class among ecoregions in the U.S. based on biological uniqueness, conservation status, and impending threats (Ricketts, 1999; Noss, 2000). The redwood region generally has mild cool rainy winters and dry summers with mean daily minimum temperatures in January ranging from $0.4-7^{\circ} \mathrm{C}$ and mean daily maximums in July range from $14-30{ }^{\circ} \mathrm{C}$ (Lorimer et al., 2009). Temperatures seldom rise above $38^{\circ} \mathrm{C}$ or drop below $-9{ }^{\circ} \mathrm{C}$. Mean annual precipitation varies along the latitudinal range from $72 \mathrm{~cm}$ in some parts of the southern region and more than $200 \mathrm{~cm}$ in the northern most part of the range but is generally more than $100 \mathrm{~cm}$ (Sawyer et al., 2000b). Redwoods are relatively poor regulators of their own water use. They can absorb water through their leaves, which is indicative of a coastal habitat preference where the atmosphere is moist (Fernández, Hamilton, \& Kueppers, 2015).

Coast redwoods and their associated community are impacted by a variety of stressors, including climate change and a variety of land use practices. The greatest overall stressor to the ecosystems of coast redwoods is intensification of the depth and duration of droughts brought on by climate change, which exacerbates pre-existing stressors that severely limit ecological function and resilience (Koopman et al., 2014). Despite high levels of genetic diversity (Douhovnikoff \& Dodd, 2011) and growth performance (Anekonda, 1992) this species appears to not have adapted to environmental gradients at the limits of its range. This has been suggested to be in part due to its predominate asexual mode of reproduction; although large quantities of seeds are generated, their viability is extremely low (Olsen, Roy, \& Walters, 1990), of short duration (Fritz \& Rydelius, 1966), and seedlings are extremely susceptible to damping off - a type of disease that leads to plant die-off before germination (Hepting, 1971). This results in a lack of recombination that would otherwise allow new adaptive gene combinations to be expressed (Douhovnikoff \& Dodd, 2011). Furthermore, coast redwood is a shallow-rooted species, which suggests that it does not benefit from access to stable groundwater reserves and is inefficient at preventing transpirational water loss (Burgess \& Dawson, 2004). The growth and reproductive physiology are likely to mean that it will be unable to adapt to present and future environmental conditions or migrate into the displaced habitat. Assisted migration therefore may be the only means for coast redwood to allow populations to match new climates.

Bioclimatic models using geographic information system (GIS) can help to identify current and projected suitable habitats and range distributions (Rehfeldt \& Jaquish, 2010; McLane \& Aitken, 2012; Notaro, Mauss, \& Williams, 2012). Items such as accuracy of future climate predictions, specific species physiological responses, and parameters outside of the data used to develop range distribution maps cause some uncertainty in modeled projections. They do however provide an indication of how climatic conditions will change. Oregon is likely to have areas on its southern coast that will encompass conditions of the small climatic envelope required by coast redwoods. This potential future habitat suitability model for coast redwoods is shown in Figure 1 to provide reference to the study area discussed in this paper. Our model assumes modest increases in temperature and modest decreases in precipitation that will have the effect of pushing redwood habitat north along the coast. 
Further description of the methods used to create this simple model are provided in section 4.2 under Methods. It's important to note that our intention for including this simplified model is to highlight the patchwork of public and private land tenure that underlies future bioclimatic envelopes for coast redwood. Please see Fernández et al. (2015) for a comprehensive model of climatically-induced future coast redwood range shifts which lays out multiple possible outcomes in the magnitude of change along a gradient of different temperature and precipitation alternatives.

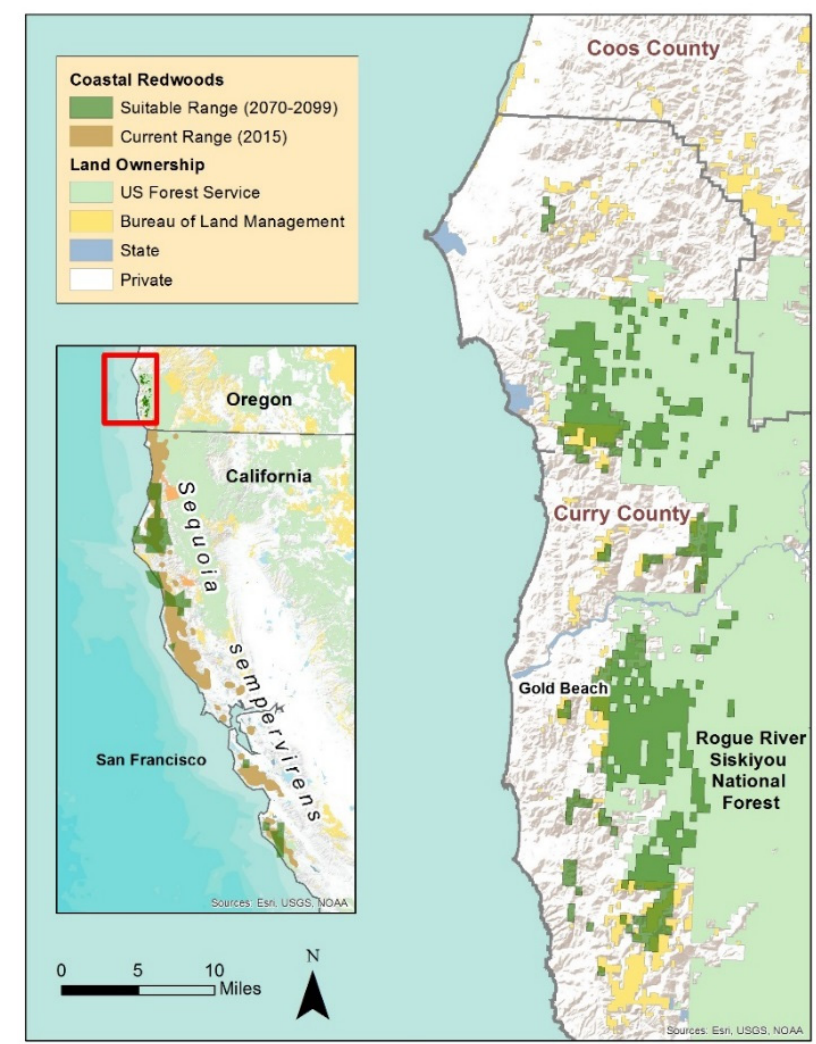

Figure 1. Future potential suitable range for coast redwoods

\subsection{The Role of Managed Migration}

Forests cover approximately $30 \%$ of Earth's terrestrial surface (42 million $\left.\mathrm{km}^{2}\right)$ and provide numerous social, economic, aesthetic, and ecological benefits across a range of spatial and temporal scales (Bonan, 2008). The goods and services provided by ecosystems to society, or ecosystem services, have been previously examined and divided into four broad categories: cultural services (e.g. recreation, aesthetics); regulating (e.g. water quality, climate control); provisioning (e.g. timber, food); and supporting (e.g. soil formation, nutrient cycling) (Millennium Ecosystem Assessment, 2005), which can all be dramatically altered due to widespread tree and forest death. Assisted migration can potentially minimize economic loss, prevent loss of biodiversity and species extinction, and sustain ecosystem services (Aubin et al., 2011; Ste-Marie, Nelson, Dabros, \& Bonneau, 2011). Assisted migration: Introduction to a multifaceted concept. The Forestry Chronicle, 87(6), 724-730.Winder, Nelson, \& Beardmore, 2011). However, the implementation of assisted migration does not come without economic, political, ecological, and ethical issues (Schwartz et al., 2012).

The level of understanding and willingness to put in place effective policies regarding the preservation of species threatened by climate change is far from adequate, which poses a major challenge for management, conservation, and preservation strategies and policies. Traditional practices of conserving and restoring biodiversity by direct appeal to historical conditions are being reconsidered in the light of rapid environmental change (Seastadt, Hobbs, \& Suding, 2008; Choi et al., 2008; McClanahan, 2008). For a species to survive the projected climate change in their current ranges they must tolerate the new conditions, or successfully colonize new areas with suitable conditions. Plant species have a very limited set of mechanisms to survive climate-induced potential 
extinction, which include plastic responses, such as changing their phenology or physiological responses, adapting to the new and changing climatic conditions via selection, or migration via seed dispersal over time (Davis \& Shaw, 2001). However, the projected rates of climate change will make it difficult or impossible for some species to survive or to move rapidly enough, especially given extensive habitat fragmentation from development (Schloss, Nuñez, \& Lawler, 2012; Zhu, Woodall, \& Clark, 2012).

Therefore, the current traditional conservation/preservation methods, such as providing migration corridors and increasing suitable habitat at range margins may need to be supplemented with a more direct, innovative, and adaptive approaches (Hunter, Dinerstein, Hoekstra, \& Lindenmayer, 2010; Krosby, Tewksbury, Haddad, \& Hoekstra, 2010). One such approach is that of managed migration (also called assisted migration/relocation and assisted colonization), which is the intentional translocation of species outside their current habitat to reduce anticipated loss of biodiversity (Vitt, Havens, Kramer, Sollinberger, \& Yates, 2010). Many scientists have stressed that ignoring or rejecting assisted migration will 'greatly increase the threat of climate-driven extinction' (McLachlan, Hellmann, \& Schwartz, 2007). Such decisions will depend significantly on the perspectives of different segments of society (policymakers, conservationists, the public) about the level of intervention needed to maintain nature for nature's sake or nature deemed valuable for human utility or amenity, and what plant communities constitute naturalized landscapes whether it be native, exotic, or novel compositions where ecological integrity is maintained (Higgs, 2003). Retention or restoration of many historic ecosystems, and/or conserving certain species in their current range may no longer be feasible; however, there are species, sites and scenarios where other options are appropriate (Hoegh-Guldberg et al., 2008).

There are numerous plant species that could benefit from human-assisted migration considering changing climatic envelopes, however to date there only a limited number of project that have gone from discourse to implementation. This is in part due to the recency of the concept, but is perhaps most attributable to the complex combination of factors needed to facilitate the process including selecting suitable future sites, public land protections or conservation easements that need to be set in place in, ongoing translocation and maintenance efforts from a committed group, and the the process of identifying species that are at risk. The Florida torreya is an example of a plant species that's critically at risk of being extirpated from its present-day narrow climatic envelope. Luckily the conifer has one such committed group, the Torreya Guardians, who have moved seedlings of the torreya taxifolia to sites northward through the Appalachians and along to Michigan and New Hampshire (Torreya Guardians, 2017).

Coast redwood is an exemplary candidate species for human assisted migration as defined by Hunter (2007), which can be characterized by three features: their probability of extinction due to climate change, their vagility (the ability of an organism to move about or in the case of plants disperse seed), and their ecological roles. However, these biological considerations are just part of the decision-making process. Much of the ecological debate can be traced back to fundamental perspectives on nature, and more particularly to the ethical question of whether to deliberately manage natural systems or to allow them to adapt or not on their own (Aubin et al., 2011). In addition to these considerations we would add to the list; potential invasiveness (i.e. ability to tolerate a variety of habitat conditions, generalists, grow and reproduce rapidly, aggressive competitors, lack of natural enemies or pests), their iconic status as a species, and the potential willingness for society to engage in the time and financial costs to save this species from possible extinction.

Technical and biological issues are central to managed relocation; however, ethical, legal, and social components pose equally challenging questions about the appropriate use and social feasibility of managed migration (Schwartz et al., 2012). Furthermore, a necessary first step towards the development and widespread success of assisted migration practices is the inclusion of biological considerations in tandem with both social and economic concerns, for which different stakeholders have their own multi-dimensional and complex objectives, metrics and definitions. Consequently, a natural science approach is limited in its capacity and/or unable to answer these questions (Sarewitz, 2004). We must therefore turn towards a more subjective understanding of land use and environmental change, one that considers how an individual's knowledge and values are situated larger societal assumptions about the role of human intervention in the environment and control over resources.

\section{Area Description}

\subsection{Land Use planning in Oregon}

One of the most important and complex social questions regarding assisted migration is that of land use policies and regulations in the area being considered. The United States, and specifically the state of Oregon, have historically had an intimate relationship with property rights, environmental discourse and environmental policy. Both country and state have experienced fluxes in a range of discourses and swings in environmental policy and 
property rights (Walker \& Hurley, 2011). The politics of land use planning in Oregon is a subject that holds an intense and passion-filled set of emotions and feelings from a wide group of players. Oregon along with Hawaii, Vermont, Florida, and California are recognized as first-generation planning states, and led what became known as the "quiet revolution," where the power to control and regulate land use returned partially or nearly entirely to state governments (Knapp \& Nelson, 1992).

In 1973, Oregon passed the country's first statewide program for land use planning, SB 100 with the initial intention to limit sprawl and protect farmlands, open spaces, and beautiful landscapes (Walker \& Hurley, 2011). The bill created the Department of Land Conservation and Development (DLCD) and the Land Conservation and Development Commission (LCDC). The LCDC's first major task was to adopt Statewide Planning Goals, which expressed the State's policies on land use and related topics to govern the development of local comprehensive land use plans. The LCDC accomplished this first task on December 27, 1974. State law requires each city and county to adopt a comprehensive plan that must be consistent with the Statewide Planning Goals, as well as ordinances regarding zoning and land-division to put the plan into effect (Knapp \& Nelson, 1992). Plans are then reviewed for consistency by the LCDC and if approved become the controlling document for land use in the area covered by the plan.

An unintended consequence of the approved land use regulations was a substantial reduction of private landowner rights. In the first decade after SB100 passed, three different statewide ballot measures $(1976,1978$ and 1982) directly challenged the legal power of state regulation in SB100, with all attempts failing. However, twice in the early 2000s the Oregon planning system nearly collapsed due to economic and political shifts in voting populations, which forced land use regulations proponents to concede important legal and conceptual ground to opponents with the passing of measure 37 and 49 (Walker \& Hurley, 2011). Measures 37 and 49 fundamentally altered land use and private landowner rights in Oregon by allowing for either compensation from the state for reductions in land value and/or altering the regulation of the land to allow landowners to do what they want with their land.

\subsection{Land Use Politics and Situated Knowledge}

With respect to the politics behind land use policy, two primary levels are available for analysis: the popular level, which helps explain why land use policies are adopted at certain locations at particular points in time, and at the interest-group level, which helps explain why land use policies take certain forms and result in particular outcomes. Hales (1991) suggests the winners in state land use planning were those able to influence state legislatures, agencies, commissions, and courts, which explains the success in protecting environmentally sensitive areas by environmentalists, protecting farmland and forest land by conservationists, and encouraging economic development by industrialists. Groups that did not fare well in their agendas included county governments who wanted to maintain local control, farmers who wanted to develop their farmland, and exclusionists who wanted to zone out lower economic groups (Hales, 1991; Knapp \& Nelson, 1992).

Land use regulation and policies, assisted migration debates and decisions, as well as many other management issues can generally be characterized by limited technical knowledge and disagreement about goals. The first step towards finding the appropriate solution is to elicit and identify the subjective beliefs - the way a person experiences things in his or her own mind, based on knowledge or opinions - behind stakeholder perspectives in order for individuals to reach an agreement on the issues at hand and the management strategies that can address these challenges (Raadgever, Mostert, \& van de Giesen, 2008). This study is focused on the subjective beliefs and perspectives of those in the Oregon land use planning community related to managed migration of coast redwoods, a topic situated in larger themes of environmental change, the role of human intervention, and the political economic considerations of land use. A major goal of this research is to provide a first step towards successful managed migration policies and strategy by developing an understanding of the current beliefs, thoughts, and subjectivity of policy makers and citizen groups in the land use planning community.

\section{Methods}

\subsection{Assessing Situated Perspectives with Q-sorts}

There has been a vast amount of literature regarding the state of Oregon's land use regulation. However, much of the literature was focused on conditions in the early 1970's as well as early 2000's. To fill in this lack of more recent knowledge, the following Q-method-based research procedure was followed. Q-method is primarily an exploratory technique. It is not a technique to test, support, or prove hypotheses (Watts \& Stenner, 2005). However, it can bring a sense of coherence to research questions that may have multiple, potentially complex and socially contested answers (Stainton Rogers, 1995) and is specifically designed for the direct measurement of an individual's subjective point of view relative to that of other individuals (Brown, 1980). 
William Stephenson first introduced Q-methodology in his letter to Nature in 1935 as an inversion of conventional factor analysis, a process in which the values of observed data are expressed as functions of a number of possible causes in order to find which are the most important (Stephenson, 1935). Q correlates persons instead of tests; "whereas previously a large number of people were given a small number of tests, [in Q] we give a small number of people a large number of test-items" (van Exel \& de Graaf, 2005). Q-methodology combines the statistical rigour of quantitative analysis with the insights of a qualitative research approach. The $\mathrm{Q}$ technique can be used to explore the nature of discourses and also has the potential to uncover unanticipated attitudes and patterns of subjective views held by a group of people.

Q-methodology systematically identifies groups of individuals with a common attitude structure by seeking patterns of responses across individuals. It is designed to elicit coherent subject positions for controlled comparison (Brown, 1980; Robbins \& Kreuger, 2000). Respondents' 'idealized accounts' or 'personal discourses' arise from inductive self-sorting of a range of statements. It also has the capacity to reveal unrecognized or underlying social 'discourses' that can represent other agendas associated with an issue. With the goal of ensuring what Armatas, Venn, and Watson (2014) refer to as 'comprehensiveness and diversity, rather than representativeness or quantity' the Q-method is 'intended to identify subjectivities that exist, not to determine how those subjectivities are distributed across a population'.

Q-sets can be constructed following one of two general paths, structured or unstructured. The selection of statements chosen from the concourse - a broad spectrum of possible opinions and perspectives developed from existing public discourse - to be used in the smaller sample Q-set may or may not be theoretically driven. In structured Q-studies statements are chosen to reflect relevant theoretical themes and an even distribution of these themes that most inclusively summarized the issues identified in the concourse, whereas in unstructured exploratory studies such as this study the Q-set does not rely on strict theoretical perspectives. Unstructured Q-studies include items presumed to be relevant to the issue being investigated and may or may not fit well into predefined thematic groupings. With unstructured Q-studies, it is possible that some aspects of the investigation might be over- or under- represented, therefore skewing could unintentionally be incorporated into the final Q-set (McKeown \& Thomas, 1988). However, one advantage of an unstructured approach is that investigators are not limited to assessing a narrow spectrum of ideas and opinions on a given issue; with unstructured Q-studies novel combinations of participant perspectives relative to one another may be elicited that were not otherwise obvious in public discourse. The unstructured Q-study is therefore useful for our purposes as an exploratory survey of perspectives about assisted migration of redwoods nested in larger societal themes of environmental change and land use planning. The methodological process in this study was completed through a series of five steps, which are the general steps of a typical Q-method study.

An unfiltered spectrum of possible opinions, beliefs, and perspectives referred to here as the concourse was developed using interviews, participant observations, scientific literature, books, newspapers, and audio recordings of recent public meetings. Preliminary interviews were also conducted during a research trip to a two-day public meeting with the DLCD on September $24^{\text {th }}$ and $25^{\text {th }}, 2015$ in Astoria, Oregon. One way this study departed from the general Q-method approach was the fact that assisted migration of redwoods into Oregon is not a current issue and does not have policies or potential future policies to construct statements around and is not an issue being discussed or debated. Therefore, the Q-set was specifically chosen and tailored to understand the subjectivity of stakeholder perspectives regarding socioeconomic and environmental issues that would be relevant if assisted migration were a proposed project and had specific policies to investigate. A list of 150 initial statements were developed for the concourse that covered a range of values associated with environmental and socio-economic views. A subset of these statements $(n=32)$ were used as the Q-set. These 32 statements are listed in Appendix A.

The P-set (set of participants) focused on participants from the two leading and most influential agencies in Oregon's land use planning community, the DLCD and the LCDC, as well as interested non-agency stakeholders (a constituency identified in Goal 1 of Oregon's Statewide Planning Goals).

The Q-sort was sent out via email to a set of agency representatives from Oregon's DLCD and LCDC as well as non-agency stakeholders, in all approximately 200 individuals were invited to participate. Each participant was asked to rank the statements from the Q-set within a predefined distribution of 32 boxes from "least agree" $(-3)$ to "most agree" $(+3)$. To ensure that participants utilize the full range of rating positions, respondents compare the statements relative to each other, which decreases the risk of arbitrary or biased sorting, and increases the repeatability of the sort (Raadgever et al., 2008). Further Q-sorting was conducted during a second research trip to another two-day public meeting with the DLCD on December $3^{\text {rd }}$ and $4^{\text {th }}, 2015$ in Salem, Oregon. During this second trip an on the spot, physical Q-sort was developed from a board with 32 cut out slots for as many 
statements printed on $3 \times 5$ index cards, which allowed us to elicit underlying perspectives from policy makers and avoid the potential lack of email responses. Each participant was asked to rank order the statements from the Q-set and then place each individual numbered statement onto a board with a predefined distribution of 32 boxes with columns from "least agree" (-3) to "most agree" $(+3)$.

Q-sort survey responses (email responses and in person card and board sorts, $\mathrm{P}=22$ in total) were analyzed in the computer program PQMethod2.35. Principle Component Analysis was used to complete a factor analysis of the 22 participant sorts. This was accomplished by rotating factors to identify the best solution using Varimax algorithm (Schmolck, 2014). Results are expressed as factor arrays which represent the general viewpoint of all the participants for each of the 32 statements. People with similar views on the statement will tend to share the same factor. The number of factors in the final set of results depends on the variability in the Q-sorts (Ghoochani, Bakhshi, Cotton, Nejad, \& Ghanian, 2015).

The analysis of Q-sorts was conducted using the statistical technique of factor analysis, which simplifies complicated data into overarching patterns by reducing many variables into a smaller set of 'factors', uncovering the latent structure of the dataset. In Q factor analysis is used to identify correlations between persons (as opposed to variables in R studies) and determines whether a set of people cluster together (rather than a set of variables).

\subsection{Assessment of Potentially Suitable Future Coast Redwoods Range}

To create a simple habitat suitability model for the potential near future range of coast redwoods temperature and precipitation data was acquired from the USGS for the average of the period between 2070 to 2099 . This range was chosen as an overall approximation to reconcile the projections of Fernández et al. (2015), which among other scenarios used 2099 for their climate project models, with the geospatial projections from Save the Redwoods League of future range distribution throughout the California coast, and the precipitation and temperature projections local to southern Oregon, which used 2070. Furthermore, this is an appropriate near future range to use as it's far enough in the future where climate will have a noticeable impact the species' bioclimatic envelope, but near enough in the future that those alive today will be around to see the impacts and decide whether to start planning for managed migration. This projected climatic data was inputted into a GIS along with the topographic constraints of coast redwoods. A score map was then developed through a GIS model with a weighted index according to the score model developed by Store et al (2003): precipitation was the most important variable (0.4), temperature (0.2) and distance from the coast $(0.2)$ as the second most important variables; and thirdly elevation (0.1) and slope $(0.1)$. Areas closer to 1 represent areas that meet the most parameters, while areas closer to 0 represent areas of less suitability, where trees may still grow though not ideally according to their natural bioclimatic habitat constraints. These near 0 values are not included since less suitable indicates an unlikeliness to persist without continual human assistance, a factor especially important for long-lived tree species like coast redwood that span multiple human generations.

\section{Results}

Q-sorting revealed a common base of agreement, as well as two shared perspectives or factors. To interpret these factors, factor scores were used, such that the three statements with the highest weighted composites were assigned +3 and the next highest were assigned +2 and so on to -3 . Their distinguishing statement sets are shown in Tables 1 and 2 . The converted factor scores were then used to interpret how the statements were ranked both within and between factors. In each case, the factor is given a label that succinctly summarizes its broader meaning (see discussion section).

The distinguishing statements for both factors are the most significant shared opinions of stakeholders in the land use planning community in Oregon based on the Q-sorts, and are therefore the defining viewpoints. The two-factor solution provided four perspectives for interpretation since a factor is defined by both positive and negative loading Q-sorts or viewpoints. The factor scores of respondents are presented in Figure 2. Summarizing the factor scores that load highest and lowest on that factor and then reinterpreting these distinguishing statements through qualitative analysis revealed links between Q-sorters' underlying values to an array of distinct socio-economic and environmental perspectives that will guide the discussion. 


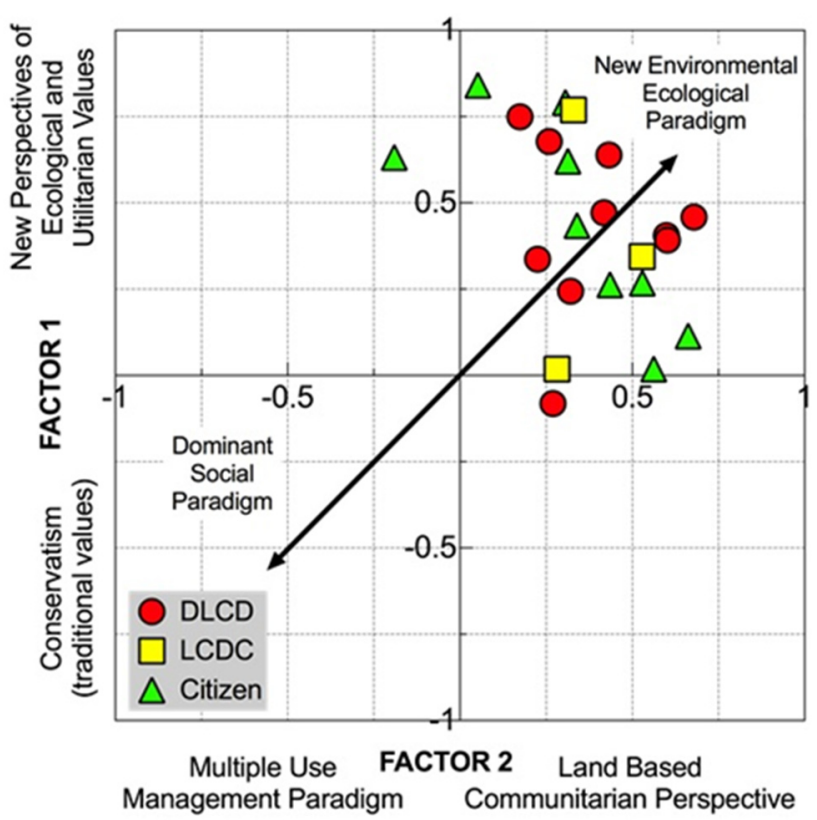

Figure 2. Axes of environmental enlightenment and socio-economic perspectives of dominant social paradigm and new environmental paradigm

\section{Discussion}

Land-use policies and decisions tend to be multidimensional and complex in terms of the number and variety of elements and interactions in the sphere of a decision-making process. In the case of coupled socio-ecological systems with a multitude of constitutive political-legal and environmental dimensions, the more complex a situation, the larger the number of plausible perspectives upon it, because it's harder to disentangle any one dimension from any other, human or natural, therefore making it difficult to prove or disapprove causation at a system level in simple terms (Dryzek, 1997). When uncertain future scenarios and policies are considered, as is the case of assisted migration of coast redwoods into Oregon, the level of complexity increases. Q-methodology was used in this study to structure the complexity of participants' subjective beliefs about environmental change and land use to reveal broader socio-ecological perspectives, i.e. shared ways of perceiving and valuing the relationship between social, economic, and environmental concerns.

For Factor 1, we frame the subjective beliefs of stakeholders in Oregon's land use planning community between two opposing, yet mutually constitutive paradigms whose conflicting viewpoints about the role of human control over nature and property rights will need to be reconciled to facilitate assisted migration of coast redwoods into Oregon. Cultural paradigms are often a combination of explicit (rules, laws, mandates) and implicit (norms, beliefs, traditions) forces. The dominant social paradigm describes the anthropocentric resource paradigm to which most citizens of capitalistic societies subscribe. The theory assumes that individual decisions, values, and attitudes are shaped by wider cultural values and beliefs. For instance, in the United States concern for the environment is often outweighed by laissez-faire attitudes and an underlying belief in perpetual abundance. In terms of the environment, adherents to this conservative paradigm hold that resources should be conserved for utilitarian use such as timber production, and as a result that nature that is valued is that which best serves humans' needs. With successive generations following the settlement of the West changing values modified the dominant social paradigm, especially concerning land management. Focus on growth, development, and capitalistic success generated opposition to the dominant paradigm and resulted in a new environmental paradigm (Dunlap \& van Liere, 1978) that blossomed in the 1960s, but sprouted much earlier through the likes of Muir and Thoreau. With the advent of television then, and more recently with thte internet, many of those living in cities who were previously disconnected from the resource degradation of the countryside and wild lands now saw the impacts of urbanization and modernity. These new communication technologies and the rising public awareness that they engendered gave rise to landmark environmental laws such at the Clean Water Act, Clean Air Act, Endangered Species Act, and National Environmental Policy Act. 
Table 1. Distinguishing statements for Factor 1 - Conservatism (traditional values) vs New Perspectives of Utilitarian Values

\begin{tabular}{l} 
Statement \\
\hline Land is part of a community to which we belong. \\
We have a history of land mismanagement in the United States, which has left us with degraded forests, \\
grasslands, and cities; that legacy requires profound reform. \\
Global sustainable land use serves the needs (for food, energy, housing, recreation etc.) of all human beings \\
living on Earth today and in the future. \\
Research and development, economic growth, and profit are more important than environmental \\
management, pollution prevention, standards of living, education, and equal opportunities. \\
Climate change is not caused by humans. \\
Land use regulation is preventing economic growth.
\end{tabular}

The findings of this exploratory unstructured Q-study analysis indicate that stakeholders researched in this study share some pro-environmental behavior. Factor 1 reflects common themes representing strong disagreement with conservatism (i.e. traditional values and ecological ignorance) and positively ranked values that align on new perspectives of ecological utilitarian values. This factor shows a high support for ideas including biological diversity, ecological function and balance, product yields, social values, and the beauty and integrity of natural environments. This perspective of utilitarian values includes a reemergence of earlier philosophical themes of maintenance of nature's balance, resource development without waste, and protection and restoration of the beauty of natural environments (Glacken, 1956) with a goal of sustaining the health, diversity, and productivity of land to serve the needs of this and future generations (Kessler, Salwasser, Cartwright, \& Caplan, 1992), which were identified as high-ranking statements in Table 1. This factor also shows strong disagreement with the notions of ecological ignorance and a mechanistic, reductionist worldview, which represent the traditional values of conservatism. These values can be summarized as seeing land primarily in terms of its capability to yield desired goods, identifying factors that limit production, the major objective of management is to remove or reduce those limitations, and relationships among different resources were treated and thought of as constraints on the dominant use (Kessler et al., 1992), all of which were identified in low ranking statements in Table 1.

Factor 2 responses show alignment on positively ranked values that share a land based communitarian perspective. Positively ranks statements of this factor shown in Table 2 demonstrate high support for land based communitarian perspective. This includes such themes as land is an essential part of our community and we are social animals, part of human and natural communities, linked to past and future generations, and dependent for our well-being on the health of the whole (Freyfogle, 1996). This factor also shows strong disagreement with the statements of multiple use resource and the scientific knowledge and technology aimed at controlling land and resource access. The traditional multiple use resource access philosophy emphasizes the production of valuable commodities, such as fiber, food, water, and minerals for human use yet also recognizes that public lands provide a special setting for aesthetic, spiritual, recreational, and educational experiences (Kessler et al., 1992), which were identified in low ranking statements in Table 2. Thus, while it may seem like aberration to say that responsdents working for the State's DLCD and LCDC value communal and more localized management of land over publically accessible resource and amenity control, one must also consider that the alignment of individuals' beliefs and perspectives are relative to the statement sort of other respondents who took part in the Q sort. That is, in Oregon the cultural beliefs and norms of both the public and those serving on commissions for state agencies not only align with one another but also embody the Oregon land use laws and regulations that they protect and benefit from. It's perhaps less about private versus public land use, and more about local control, which so happens to be more easily achievable through communitarian management of private lands than public multiple use lands controlled by the federal government or even the state.

As an artifact of the unstructured nature of this Q-study, the distribution of respondent perspectives from the survey shows a single general grouping of all respondents on the positive side of both defined axes. This convergence suggests ecological awareness and environmental enlightenment as opposed to the view of favoring man's dominion over nature. This recognition that human activities are altering the ecosystems on which our existence -and that of all living species - is dependent is transforming our relationship with the physical environment (Milbrath \& Fisher, 1984), and the growing acknowledgement of achieving more sustainable forms of development, land use practices, and relationships with nature has previously been defined as the new environmental paradigm (Dunlap \& Van Liere, 1978). The bold black line intersecting the two defined axes in Figure 2 shows the difference between the dominant social paradigm, which prioritizes hard-power industrial 
development over nature preservation and health risks, and that of the new environmental paradigm which stresses risk avoidance, generalized compassion for nature and future generations, limits to growth, and a simple participatory, post-materialistic lifestyle that requires regulation of development held by the respondents of the Oregon land use planning community.

What does all this mean to the possible future of developing and implementing a successful policy of assisted migration of coast redwoods into Oregon? The diversity of thought required to see, understand, and possibly implement land use policies that will be needed to save a species such as coast redwoods from human caused climatically-induced extinction is vast and confusing. It does and will continue to encompass varied ways of recognizing moral worth in other species, ecological communities, and future generations of humans; as well as deep individually held and often inconsistent or changing factors involved in making moral judgments, including background, education, politics, economics, and religion. There is also the need for our long-held commitment to individuality and property rights to transition to a mode of thought that joins land and people together into a larger community by making it clear that land is an essential part of that community, that land and community are far more than their market equivalents, and that a proper land use is not just property as commodity.

Table 2. Distinguishing statements for Factor 2 - Multiple Use Management Paradigm vs Land Based Communitarian Perspective

\begin{tabular}{|c|c|c|}
\hline Statement & Rank & $z$-score \\
\hline Living human beings do have obligations towards future generations. & 3 & 2.43 \\
\hline $\begin{array}{l}\text { Natural resources should be used in a manner that will meet present day needs for resources without } \\
\text { jeopardizing the supply of resources for future generations. }\end{array}$ & 3 & 1.64 \\
\hline Land use regulation should safeguard timber resources to secure future supply. & 2 & 1.29 \\
\hline $\begin{array}{l}\text { Goal } 4 \text { of the Oregon Statewide Planning Goals addresses issues related to "maintain[ing] the forest land } \\
\text { base and [protecting] the state's forest economy". I see preserving and dedicating land to managed } \\
\text { migration of coastal redwood trees as being in direct opposition to Goal } 4 \text {. }\end{array}$ & -2 & -1.45 \\
\hline $\begin{array}{l}\text { It would require the adoption of a new statewide planning goal regarding preserving land for managed } \\
\text { migration in order for any agency in the land use planning community to really have an influence. }\end{array}$ & -2 & -1.28 \\
\hline $\begin{array}{l}\text { Lands and their natural resources should not be consumed by humans and should instead be maintained in } \\
\text { as close to "pristine" form possible. }\end{array}$ & -3 & -1.97 \\
\hline
\end{tabular}

\section{Conclusion}

What this study has shown is the values needed for assisted migration are in place in the three groups involved in the land use planning community in Oregon that were part of this survey. It appears that the new environmental paradigm may align with individuals actively involved in land use planning in Oregon. Moreover, land use planning needs to put the human bond with nature and land in the foreground, rather than treating it as interesting but unworthy of taking out of the background of planning. The take away message from this study is simple: in the land use planning community in Oregon, there lies promise and hope for the future of a successful policy to save threatened species such as coast redwoods from human caused extinction.

\section{Acknowledgments}

The authors would like to thank Professor Brent Haddad of the Department of Environmental Studies, University of California, Santa Cruz, for his advisory role that helped to shape the initial ideas of this paper related to land use planning in Oregon. The authors would also like to thank Jessie Klovee, an undergraduate student in the Department of Environmental Studies for the geographic information systems analysis she conducted to determine potential future suitable habitat for coast redwoods in Oregon.

\section{References}

Adams, H. D., Guardiola-Claramonte, M., Barron-Gafford, G. A., Villegas, J. C., Breshears, D. D., Zou, C. B., ..., \& Huxman, T. E. (2009). Temperature sensitivity of drought-induced tree mortality portends increased regional die-off under global-change-type drought. Proceedings of the National Academy of Sciences of the United States of America, 106(17), 7063-7066. https://doi.org/10.1073/pnas.0901438106

Allen, C. D., Macalady, A. K., Chenchouni, H., Bachelet, D., McDowell, N., Vennetier, M., ..., \& Hogg, E. T. (2010). A global overview of drought and heat-induced tree mortality reveals emerging climate change risks for forests. Forest Ecology and Management, 259(4), 660-684. https://doi.org/10.1016/j.foreco.2009.09.001 
Anekonda, T. S. (1992). A genetic architecture study of coast redwood. Doctoral Thesis. University of California, Berkeley.

Armatas, C. A., Venn, T. J., \& Watson, V. E. (2014). Applying Q-methodology to select and define attributes for non-market valuation: A case study from Northwest Wyoming, United States. Ecological Economics, 107, 447-456. https://doi.org/10.1016/j.ecolecon.2014.09.010

Aubin, I., Garbe, C. M., Colombo, S., Drever, C. R., McKenney, D. W., Messier, C., ..., \& Wellstead, A. M. (2011). Why we disagree about assisted migration 1: Ethical implications of a key debate regarding the future of Canada's forests. The Forestry Chronicle, 87(6), 755-765. https://doi.org/10.5558/tfc2011-092

Benton, M. J., \& Twitchett, R. J. (2003). How to kill (almost) all life: The end-Permian extinction event. Trends in Ecology and Evolution, 18(7), 358-365. https://doi.org/10.1016/S0169-5347(03)00093-4

Bonan, G. (2008). Forests and climate change: Forcings, feedbacks, and the climate benefits of forests. Science, 320(5882), 1444-1449. https://doi.org/10.1126/science.1155121

Boyer, J. (1982). Plant productivity and environment. Science, 218(4571), 443-448. https://doi.org/10.1126/ science.218.4571.443

Brown, S. (1980). Political subjectivity: Applications of Q Methodology in political science. Yale University Press, New Haven CT.

Burgess, S. O., \& Dawson, T. E. (2004). The contribution of fog to the water relations of Sequoia sempervirens: Foliar uptake and prevention of dehydration. Plant, Cell, \& Environment, 27(8), 1023-1034. https://doi.org/ $10.1111 / \mathrm{j} .1365-3040.2004 .01207 . \mathrm{x}$

Choi, Y. D., Temperton, V. M., Allen, E. B., Groojans, A. P., Halassy, M., \& Hobbs, R. J. (2008). Ecological restoration for future sustainability in a changing environment. Ecoscience, 15(1), 53-64 https://doi.org/10. 2980/1195-6860(2008)15[53:ERFFSI]2.0.CO;2

Crowl, T. A., Crist, T. O., Parmenter, R. R., Belovsky, G., \& Lugo, A. E. (2008). The spread of invasive species and infectious disease as drivers of ecosystem change. Frontiers in Ecology and Environment, 6(5), 238246 https://doi.org/10.1890/070151

Davis, M. B., \& Shaw, R. G. (2001). Range shifts and adaptive responses to Quaternary climate change. Science, 292(5517), 673-679. https://doi.org/10.1126/science.292.5517.673

Douhovnikoff, V., \& Dodd, R. S. (2011). Lineage divergence in coast redwood (Sequoia sempervirens), detected by a new set of nuclear microsatellite loci. The American Midland Naturalist, 165(1), 22-37. https://doi.org/ 10.1674/0003-0031-165.1.22

Dryzek, J. (1997). Politics of the Earth: Environmental discourses. Oxford University Press, Oxford, UK.

Dunlap, R. E., \& Van Liere, K. D. (1978). The "new environmental paradigm". The Journal of Environmental education, 9(4), 10-19. https://doi.org/10.1080/00958964.1978.10801875

Fernández, M., Hamilton, H. H., \& Kueppers, L. M. (2015). Back to the future: using historical climate variation to project near-term shifts in habitat suitable for coast redwood. Global Change Biology, 21(11), 4141-4152. https://doi.org/10.1111/gcb.13027

Freyfogle, E. T. (1996). Ethics, Community, and Private Land Ethics. Ecology Law Quarterly, 23(4), 631. http://dx.doi.org/doi:10.15779/Z38HC3M

Fritz, E., \& Rydelius, J. A. (1966). Redwood reforestation problems: an experimental approach to their solution. Foundation for American Resource Management, San Francisco, CA.

Ghoochani, O. M., Bakhshi, A., Cotton, M., Nejad, A. H., \& Ghanian, M. (2015). Environmental values in the petrochemical industry: A Q-method study in South West Iran. Environmental \& Socio-economic Studies, 3(4), 1-10. http://doi.org/doi:10.1515/environ-2015-0068

Glacken, C. J. (1956). The origins of the conservation philosophy. Journal of Soil and Water Conservation, 11(2), 63-66.

Hales, C. (1991). Higher density + certainty $=$ affordable housing for Portland, Oregon. Urban Land, 50(9), 12-15.

Harris, J. A., Hobbs, R. J., Higgs, E., \& Aronson, J. (2006). Ecological restoration and global climate change. Restoration Ecology, 14(2), 170-176. https://doi.org/10.1111/j.1526-100X.2006.00136.x 
Hepting, G. H. (1971). Diseases of forest and shade trees of the United States. U.S. Department of Agriculture, Agricultural Handbook. Pp. 386.

Higgs, E. (2003). Nature by design: People, natural process, and ecological restoration. MIT Press, Cambridge, MA.

Hobbs, R. J., Higgs, E., \& Harris, J. A. (2009). Novel ecosystems: implications for conservation and restoration. Trends in Ecology and Evolution, 24(11), 599-605. https://doi.org/10.1016/j.tree.2009.05.012

Hoegh-Guldberg, O., Hughes, L., McIntyre, S., Lindenmayer, D. B., Parmesan, C., Possingham, H., \& Thomas, C. D. (2008). Assisted colonization and rapid climate change. Science, 321(5887), 345-346. https://doi.org/ 10.1126/science. 1157897

Houghton, J. T., Ding, Y., Griggs, D. J., Noguer, M., van der Linden, P. J., Dai, X., ..., \& Johnson, C. A. (2001). Climate change 2001: The scientific basis. Contributions of Working Group I to the Third Assessment Report of the Intergovernmental Panel on Climate Change. Cambridge University Press, Cambridge, UK.

Hulme, P. E. (2005). Adapting to climate change: is there scope for ecological management in the face of a global threat? Journal of Applied ecology, 42(5), 784-794. https://doi.org/10.1111/j.1365-2664.2005.01082.x

Hunter, M., Dinerstein, E., Hoekstra, J., \& Lindenmayer, D. (2010). A call to action for conserving biological diversity in the face of climate change. Conservation Biology, 24(5), 1169-1170. https://doi.org/10.1111/j. 1523-1739.2010.01569.x

Jiang, X., Rauscher, S., Ringler, T., Lawrence, D., Williams, A., Allen, C., ..., \& McDowell, N. (2013). Projected future changes in vegetation in Western North America in the twenty-first century. Journal of Climate, 26(11), 3671-3687. https://doi.org/10.1175/JCLI-D-12-00430.1

Johnstone, J. A., \& Dawson, T. E. (2010). Climatic context and ecological implications of summer fog decline in the coast redwood region. Proceedings of the National Academy of Sciences of the United States of America, 107(10), 4533-4538. https://doi.org/10.1073/pnas.0915062107

Kessler, W. B., Salwasser, H., Cartwright Jr, C. W., \& Caplan, J. A. (1992). New perspectives for sustainable natural resources management. Ecological Applications, 2(3), 221-225. https://doi.org/10.2307/1941856

Knapp, G., \& Nelson, A. (1992). The regulated landscape: Lessons on state land use planning from Oregon. Lincoln Institute of Land Policy, Cambridge, MA.

Koopman, M., Dellasala, D., van Mantgem, P., Blom, B., Teraoka, J., Shearer, R., ..., \& Seney, J. (2014). Managing an ancient ecosystem for the modern world: Coast redwoods and climate change. GEOS Insitute.

Krosby, M., Tewksbury, J., Haddad, N., \& Hoekstra, J. (2010). Ecological connectivity for a changing climate. Conservation Biology, 24(6), 1686-1689. https://doi.org/10.1111/j.1523-1739.2010.01585.x

Loarie, S. R., Carter, B. E., Hayhoe, K., McMahon, S., Moe, R., Knight, C. A., \& Ackerly, D. D. (2008). Climate change and the future of California's endemic flora. PloS One, 3(6), 2502. https://doi.org/10.1371/ journal.pone. 0002502

Logo, E. (2013). Q-methodology method based environmental awareness measurement in transportation. International Journal of Traffic Transportation Engineering, 3(1), 45-53. https://doi.org/10.7708/ijtte. 2013.3 (1).04

Lorimer, C. G., Porter, D. J., Madej, M. A., Stuart, J. D., Veirs, S. D., Norman, S. P., \& Libby, W. J. (2009). Presettlement and modern disturbance regimes in coast redwood forests: Implications for the conservation of old-growth stands. Forest Ecology and Management, 258(7), 1038-1054. https://doi.org/10.1016/j.foreco. 2009.07.008

McClanahan, T. R., Cinner, J. E., Maina, J., Graham, N. A. J., Daw, T. M., Stead, S. M., \& Wamukota, A. (2008). Conservation action in a changing climate. Conservation Letters, 1(2), 53-59. https://doi.org/10. 1111/j.1755-263X.2008.00008_1.X

McKeown, B., \& Thomas, D. (1988). Q Methodology. Sage, Newbury Park, CA. https://doi.org/10.4135/97814 12985512

McLachlan, J. S., Hellmann, J. J., \& Schwartz, M. W. (2007). A framework for debate of assisted migration in an era of climate change. Conservation Biology, 21(2), 297-302. https://doi.org/10.1890/11-0329.1 
McLane, S. C., \& Aitken, S. N. (2012). Whitebark pine (Pinus albicaulis) assisted migration potential: testing establishment north of the species range. Ecological Applications, 22(1), 142-153. https://doi.org/10.1890/ 11-0329.1

Milbrath, L. W., \& Fisher, B. V. (1984). Environmentalists: Vanguard for a new society. SUNY Press.

Millennium Ecosystem Assessment [MEA]. (2005). Ecosystems and human well-being: General synthesis. World Resources Institute, Washington, DC.

Metz, M. R., Varner, J. M., Frangioso, K. M., Meentemeyer, R. K., \& Rizzo, D. M. (2013). Unexpected redwood mortality from synergies between wildfire and an emerging infectious disease. Ecology, 94(10), 2152-2159. https://doi.org/10.1890/13-0915.1

Nemani, R., Keeling, C., Hashimoto, H., Jolly, W., Piper, S., Tucker, C., .., \& Running, S. (2003). Climate driven increases in global terrestrial net primary production from 1982 to 1999. Science, 300(5625), 1560 1563. https://doi.org/10.1126/science. 1082750

Noss, R. F. (1999). The redwood forest: History, ecology, and conservation of the coast redwoods. Island Press, Washington, DC.

Noss, R. F. (2000). High-risk ecosystems as foci for considering biodiversity and ecological integrity in ecological risk assessments. Environmental Science \& Policy, 3(6), 321-332. https://doi.org/10.1016/S1462 -9011(00)00112-X

Notaro, M., Mauss, A., \& Williams, J. W. (2012). Projected vegetation changes for the American Southwest: combined dynamic modeling and bioclimatic-envelope approach. Ecological Applications, 22(4), 1365-1388. https://doi.org/10.1890/11-1269.1

Olsen, D. F., Roy, D. F., \& Walters, G. A. (1990). Sequoia sempervirens. In: Silvics of North America. U.S. Department of Agriculture. Agricultural Handbook 654, Pp. 541-551.

Parmesan, C., \& Yohe, G. (2003). A globally coherent fingerprint of climate change impacts across natural systems. Nature, 421(6918), 37-42. https://doi.org/10.1038/nature01286

Raadgever, G. T., Mostert, E., \& van de Giesen, N. C. (2008). Identification of stakeholder perspectives on future flood management in the Rhine basin using Q methodology. Hydrology and Earth System Sciences, 12(4), 1097-1109. https://doi.org/10.5194/hess-12-1097-2008

Rehfeldt, G. E., \& Jaquish, B. C. (2010). Ecological impacts and management strategies for western larch in the face of climate-change. Mitigation and Adaptation Strategies for Global Change, 15(3), 283-306. https://doi.org/10.1007/s11027-010-9217-2

Ricketts, T. H. (1999). Terrestrial ecoregions of North America: A conservation assessment (Vol. 1). Island Press, Washington, DC.

Robbins, P., \& Kreuger, R. (2000). Beyond bias: the promise and limits of Q-methodology in human geography. Professional Geographer, 52(4), 636-649. https://doi.org/10.1111/0033-0124.00252

Root, T. L., Price, J. T., Hall, K. R., Schneider, S. H., Rosenzweig, C., \& Pounds, J. A. (2003). Fingerprints of global warming on wild animals and plants. Nature, 421(6918), 57-60. https://doi.org/10.1038/nature01333

Root, T. L., \& Schneider, S. H. (2006). Conservation and climate change: the challenges ahead. Conservation Biology, 20(3), 706-708. https://doi.org/10.1111/j.1523-1739.2006.00465.x

Sarewitz, D. (2004). How science makes environmental controversies worse. Environmental Science \& Policy, 7(5), 385-403. https://doi.org/10.1016/j.envsci.2004.06.001

Sawyer, J. O., Sillett, S. C., Popenoe, J. H., LaBanca, A., Sholars, T., Largent, D. L., ..., \& Van Pelt, R. (2000a). Characteristics of redwood forests. In The redwood forest: History, ecology, and conservation of the coast redwoods (pp. 39-79). Island Press, Washington, DC.

Sawyer, J. O., Sillett, S. C., Libby, W. J., Dawson, T. E., Popenoe, J. H., Largent, D. O., ..., \& Noss, R. F. (2000b). Redwood trees, communities and ecosystems: a closer look. In R. F. Noss (Ed.), The redwood forest: History, ecology, and conservation of the coast redwoods (pp. 81-118). Island Press, Washington, DC.

Schloss, C. A., Nuñez, T. A., \& Lawler, J. J. (2012). Dispersal will limit ability of mammals to track climate change in the Western Hemisphere. Proceedings of the National Academy of Sciences, 109(22), 8606-8611. https://doi.org/10.1073/pnas.1116791109 
Schmolck, P. (2014). PQMethod Manual. Retrieved July 12, 2016, http://schmolck.org/qmethod/pqmanual.htm

Schwartz, M. W., Hellmann, J. J., McLachlan, J. M., Sax, D. F., Borevitz, J. O, Brennan, J., ..., \& Doremus, H. (2012). Managed relocation: integrating the scientific, regulatory, and ethical challenges. BioScience, 62(8), 732-743. https://doi.org/10.1525/bio.2012.62.8.6

Seastadt, T. R., Hobbs, R. J., \& Suding, K. N. (2008). Management of novel ecosystems: Are novel approaches required? Frontiers in Ecology and Environment, 6(10), 547-553. https://doi.org/10.1890/070046

Stainton Rogers, R. (1995). Q methodology. In J. A. Smith, R. Harré, \& L. Van Langenhove (Eds.), Rethinking methods in psychology. Sage, London, UK. https://doi.org/10.4135/9781446221792.n12

Ste-Marie, C., Nelson, A., Dabros, E., \& Bonneau, A. (2011). Assisted migration: Introduction to a multifaceted concept. The Forestry Chronicle, 87(6), 724-730. https://doi.org/10.5558/tfc2011-089

Stephenson, W. (1935). Technique of factor analysis. Nature, 136, 297. https://doi.org/10.1038/136297b0

Store, R., \& Jokimäki, J. (2003). A GIS-based multi-scale approach to habitat suitability modeling. Ecological Modelling, 169(1), 1-15. https://doi.org/10.1016/S0304-3800(03)00203-5

Thomas, C. D., Cameron, A., Green, R. E., \& Williams, S. E. (2004). Extinction risk from climate change. Nature, 427(6970), 145-148. https://doi.org/10.1038/nature02121

Torreya Guardians. (2017). Citizen science climate activism. Retrieved May 18, 2017, from http://www.torreya guardians.org/

Van Exel, N., \& de Graaf, G. (2005). $Q$ methodology: A sneak preview. Retrieved July 12, 2016, www.jobvanexel.nl.

Vitt, P., Havens, K., Kramer, A., Sollinberger, D., \& Yates, E. (2010). Assisted migration of plants: Changes in latitudes, changes in attitudes. Biological Conservation, 143(1), 18-27. https://doi.org/10.1016/ j.biocon.2009.08.015

Walker, P., \& Hurley, P. (2011). Planning Paradise. University of Arizona Press, Tucson, AZ.

Watts, S., \& Stenner, P. (2005). Doing Q methodology: theory, method and interpretation. Qualitative Research in Psychology, 2(1), 67-91. https://doi.org/10.1191/1478088705qp022oa

Westerling, A. L., Bryant, B. P., Preisler, H. K., Holme, T. P., Hidalgo, H. G., Das, T., \& Shrestha, S. R. (2011). Climate change and growth scenarios for California wildfire. Climatic Change, 109(1), 445-463. https://doi.org/10.1007/s10584-011-0329-9

Winder, R., Nelson, E., \& Beardmore, T. (2011). Ecological implications for assisted migration in Canadian forests. The Forestry Chronicle, 87(6), 731-744. https://doi.org/10.5558/tfc2011-090

Zhu, K., Woodall, C. W., \& Clark, J. S. (2012). Failure to migrate: lack of tree range expansion in response to climate change Global Change Biology, 18(3), 1042-1052. https://doi.org/10.1111/j.1365-2486.2011.02571.x

\section{Appendix}

Statements composing the Q-set

1. We have a history of land mismanagement in the United States, which has left us with degraded forests, grasslands, and cities; that legacy requires profound reform.

2. Living human beings do have obligations towards future generations.

3. Dedicating areas of land in the Oregon Coastal Zone for the preservation of coastal redwood trees via managed migration and restricting logging or other deleterious land uses in the future will create many great life long jobs for Oregon residents.

4. Land use regulation is preventing economic growth.

5. It would require the adoption of a new statewide planning goal regarding preserving land for managed migration in order for any agency in the land use planning community to really have an influence.

6. The current level of forest protection is inadequate.

7. Global sustainable land use serves the needs (for food, energy, housing, recreation etc.) of all human beings living on Earth today and in the future.

8. Land is part of a community to which we belong.

9. Standard of living, community, and equal opportunities are more important than profit, economic growth, protection of natural resources, and pollution prevention.

10. Land use regulation should ensure that negative environmental impacts of logging are controlled to acceptable levels of risk.

11. Public lands are "special settings" for recreational, spiritual, aesthetic, and educational experience. Preserving and protecting land 
areas and saving threatened species through managed migration will enhance the great social rewards of these "special settings".

12. Land use regulation should safeguard timber resources to secure future supply.

13. Lands and their natural resources should not be consumed by humans and should instead be maintained in as close to "pristine" form possible.

14. Local governments should have the authority to adopt laws to protect natural resources, which by-pass the need for State regulatory approval. An example could include a law which facilitates the managed migration of plant species northward due to threats to their current habitat resulting from climate change.

15. Land is a commodity that belongs to us.

16. Protection of natural resources, pollution prevention, and environmental management are more important than economic growth, profit, standards of living, and equal opportunities.

17. To preserve and maintain agricultural land through farm zoning should not include preservation land to save trees from potential extinction from a changing climate.

18. Saving threatened species from the next great extinction event should not be restricted through state land use regulations.

19. Human activity has produced the global warming we are witnessing and the consequent pressure on many species, necessitating that we intervene in ways that may help save species from extinction.

20. I love nature and wilderness but a successful and thriving economy is more important and will actually protect nature and wilderness more than restrictions and regulations.

21. The value of the environment is in the goods and services it can provide to people.

22. Natural resources should be used in a manner that will meet present day needs for resources without jeopardizing the supply of resources for future generations.

23. Citizens should have the opportunity to engage in managed migration of coastal redwood trees on the land they own.

24. In 2015, Oregon's Land Conservation and Development Community's Strategic Plan stated its goal to "Develop a "non-resource lands" policy that is integrated with resource lands protection strategies, including consideration of carrying capacity, environmental and habitat protection, infrastructure requirements and availability and other factors. There are currently no standards to guide counties in identifying and zoning non-resource lands". I believe dedicating protected land for managed migration to save coastal redwood trees from extinction should be included in such a "non-resource lands" policy.

25. Forest land should be maintained to provide long-term economic opportunities for timber and logging activities.

26. The American Planning Association's 2002 Growing Smart Legislative Guidebook explains, "States and communities across the country are slowly, but increasingly, realizing that simply responding to natural disasters, without addressing ways to minimize their potential effect, is no longer an adequate role for government." Land use regulation should include means to prevent loss of species such as the coastal redwood Sequoia sempervirens, which is arguably the tallest living organism that has ever existed on Earth and one of the most massive, because biodiversity loss and species extinction are natural disasters.

27. Research and development, economic growth, and profit are more important than environmental management, pollution prevention, standards of living, education, and equal opportunities.

28. Policies should be in place that promotes sound pre- and post-logging site evaluation to ensure best management practices for a healthy future ecosystem.

29. Goal 4 of the Oregon Statewide Planning Goals addresses issues related to "maintain[ing] the forest land base and [protecting] the state's forest economy". I see preserving and dedicating land to managed migration of coastal redwood trees as being in direct opposition to Goal 4.

30. The focus should not only be on saving a species or on the land itself, but equal thought should be given to those who use the land and live on it.

31. It will not be possible to save all species threatened by climate change, but efforts should be made to save the coastal redwood Sequoia sempervirens.

32. Climate change is not caused by humans.

\section{Copyrights}

Copyright for this article is retained by the author(s), with first publication rights granted to the journal.

This is an open-access article distributed under the terms and conditions of the Creative Commons Attribution license (http://creativecommons.org/licenses/by/4.0/). 